\title{
ANTIBIOTIKA, RESISTENSI, DAN RASIONALITAS TERAPI
}

\author{
Eka Rahayu Utami \\ Fakultas Sains dan Tekhnologi UIN Maliki Malang. \\ Email: ekhoney_mom@yahoo.com
}

\begin{abstract}
Bacterial resistance toward antibiotics has become international and serious problem. Rasional therapy campaign has common recently, include correct medication, precise dose, fix therapy periode and efficient cost. Microbes being resistance through some different ways for live survival. Many things can cause this resistance. In the end, there are a lot of harmful consequences in health, economic, also public health aspect. Rational therapy, government regulation, and civil education become some crusial point in bacterial resistance conquer strategy.
\end{abstract}

Keywords: antibiotics, resistance, rational therapy.

\section{PENDAHULUAN}

Antibiotika, yang pertama kali ditemukan oleh Paul Ehlrich pada 1910, sampai saat ini masih menjadi obat andalan dalam penanganan kasus-kasus penyakit infeksi. Pemakaiannya selama 5 dekade terakhir mengalami peningkatan yang luar biasa, hal ini tidak hanya terjadi di Indonesia tetapi juga menjadi masalah di negara maju seperti Amerika Serikat. The Center for Disease Control and Prevention in USA menyebutkan terdapat 50 juta peresepan antibiotik yang tidak diperlukan (unnescecery prescribing) dari 150 juta peresepan setiap tahun (Akalin,2002). Menurut Menteri Kesehatan Endang Rahayu Sedyaningsih, sekitar 92 persen masyarakat di Indonesia tidak menggunakan antibiotika secara tepat. Ketika digunakan secara tepat, antibiotik memberikan manfaat yang tidak perlu diragukan lagi. Namun bila dipakai atau diresepkan secara tidak tepat (irrational prescribing) dapat menimbulkan kerugian yang luas dari segi kesehatan, ekonomi bahkan untuk generasi mendatang.

$$
\text { Munculnya kuman-kuman }
$$
patogen yang kebal terhadap satu (antimicrobacterial resistance) atau beberapa jenis antibiotika tertentu (multiple drug resistance) sangat menyulitkan proses pengobatan. Pemakaian antibiotika lini pertama yang sudah tidak bermanfaat harus diganti 
dengan obat-obatan lini kedua atau bahkan lini ketiga. Hal ini jelas akan merugikan pasien, karena antibiotika lini kedua maupun lini ketiga masih sangat mahal harganya. Sayangnya, tidak tertutup kemungkinan juga terjadi kekebalan kuman terhadap antibiotika lini kedua dan ketiga. Disisi lain, banyak penyakit infeksi yang merebak karena pengaruh komunitas, baik berupa epidemi yang berdiri sendiri di masyarakat (independent epidemic) maupun sebagai sumber utama penularan di rumah sakit (nosocomial infection). Apabila resistensi terhadap pengobatan terus berlanjut tersebar luas, dunia yang sangat telah maju dan canggih ini akan kembali ke masa-masa kegelapan kedokteran seperti sebelum ditemukannya antibiotika (APUA, 2011).

Hal-hal diatas telah menjadi permasalahan kesehatan di seluruh dunia. Hingga akhirnya pada peringatan Hari Kesehatan Internasional tahun 2011, WHO menetapkan tema Antimicrobacterial Resistance and its Global Spread. Sejalan dengan tema WHO, Indonesia mengangkat tema “Gunakan Antibiotik Secara Tepat untuk Mencegah Kekebalan Kuman”. Resistensi kuman terhadap antibiotika berkembang jauh lebih cepat daripada penelitian dan penemuan antibiotika baru. Saat ini sedang digalakkan kampanye dan sosialisasi pengobatan secara rasional yang meliputi pengobatan tepat, dosis tepat, lama penggunaan yang tepat serta biaya yang tepat. No action today, no cure tomorrow.

\section{ANTIBIOTIKA DAN RESISTENSI}

Penemuan antibiotik diinisiasi oleh Paul Ehrlich yang pertama kali menemukan apa yang disebut "magic bullet', yang dirancang untuk menangani infeksi mikroba. Pada tahun 1910, Ehrlich menemukan antibiotika pertama, Salvarsan, yang digunakan untuk melawan syphilis. Ehrlich kemudian diikuti oleh Alexander Fleming yang secara tidak sengaja menemukan penicillin pada tahun 1928 . Tujuh tahun kemudian,Gerhard Domagk menemukan sulfa, yang membuka jalan penemuan obat anti TB, isoniazid. Pada 1943, anti TB pertama ,streptomycin, ditemukan oleh Selkman Wakzman dan Albert Schatz. Wakzman pula orang pertama yang memperkenalkan terminologi antibiotik. Sejak saat itu antibiotika ramai digunakan klinisi untuk 
menangani berbagai penyakit infeksi (Zhang, 2007).

Antimikroba adalah obat yang digunakan untuk memberantas infeksi mikroba pada manusia. Sedang antibiotika adalah senyawa kimia yang dihasilkan oleh mikroorganisme (khususnya dihasilkan oleh fungi) atau dihasilkan secara sintetik yang dapat membunuh atau menghambat perkembangan bakteri dan organisme lain (Munaf, 1994).

Secara garis besar antimikroba dibagi menjadi dua jenis yaitu yang membunuh kuman (bakterisid) dan yang hanya menghambat pertumbuhan kuman (bakteriostatik). Antibiotik yang termasuk golongan bakterisid antara lain penisilin, sefalosporin, aminoglikosida (dosis besar), kotrimoksazol, rifampisin, isoniazid dan lain-lain. Sedangkan antibiotik yang memiliki sifat bakteriostatik, dimana penggunaanya tergantung status imunologi pasien, antara lain sulfonamida, tetrasiklin, kloramfenikol, eritromisin, trimetropim, linkomisin, klindamisin, asam paraaminosalisilat, dan lain-lain (Laurence \& Bennet,1987).

Pembagian bakteriostatik dan bakterisid ini tidak absolut, tergantung dari konsentrasi obat, spesies bakteri dan fase perkembangannya. Manfaat dari pembagian ini berguna dalam hal pemilihan antibiotika, pada pasien dengan status imunologi yang rendah (imunosuppressed) misalnya penderita HIV-AIDS, pada pasien pembawa kuman (carrier), pada pasien dengan kondisi sangat lemah (debilitated) misalnya pada pasien-pasien end-stage, maka harus dipilih antibiotika bakterisid.

Terdapat pembagian lain dalam klasifikasi antibiotika, yaitu berdasar cara kerja maupun spektrum kerjanya. Penggunaan pembagian ini secara klinis masih kurang bermanfaat. Dalam prakteknya, klasifikasi yang paling sering dipakai klinisi adalah berdasar susunan senyawa kimia. Lebih sering dipakai karena sifatnya yang praktis, nama obat yang dipakai langsung terkait dengan golongan senyawa kimia masing-masing. Antibiotika yang dibagi berdasar senyawa kimianya antara lain golongan penicillin, cephalosporin, amfenikol, aminoglikosida, tetrasiklin, makrolida, linkosamid, polipeptida, dan antimikobakterium.(kucers, use of antibiotic)

Di samping antibiotika yang telah disebutkan di atas, akhir-akhir ini 
juga mulai diperkenalkan jenis-jenis baru dari golongan beta laktam misalnya kelompok monosiklik beta laktam yakni aztreonam, yang terutama aktif terhadap kuman Gram negatif, termasuk pseudomonas. Juga antibiotika karbapenem (misalnya imipenem) yang dikatakan tahan terhadap penisilinase dan aktif terhadap kuman-kuman Gram positif dan Gram negatif.

Antibiotika dapat ditemukan dalam berbagai sediaan, dan penggunaanya dapat melalui jalur topical, oral, maupun intravena. Banyaknya jenis pembagian, klasifikasi, pola kepekaan kuman, dan penemuan antibiotika baru seringkali menyulitkan klinisi dalam menentukan pilihan antibiotika yang tepat ketika menangani suatu kasus penyakit. Hal ini juga merupakan salah satu faktor pemicu terjadinya resistensi.

Tidak mengherankan apabila bakteri dapat dengan mudah beradaptasi dengan paparan antibiotika, mengingat keberadaan dan perkembanganya telah dimulai sejak kurang lebih 3,8 milyar tahun yang lalu. Resistensi pasti diawali adanya paparan antibiotika, dan meskipun hanya ada satu atau dua bakteri yang mampu bertahan hidup, mereka punya peluang untuk menciptakan satu galur baru yang resisten. Sayangnya, satu galur baru yang resisten ini bisa menyebar dari satu orang ke orang lain, memperbesar potensinya dalam proporsi epidemik. Penyebaran ini dipermudah oleh lemahnya control infeksi dan penggunaan antibiotika yang luas (Peterson, 2005)

Resistensi didefinisikan sebagai tidak terhambatnya pertumbuhan bakteri dengan pemberian antibiotik secara sistemik dengan dosis normal yang seharusnya atau kadar hambat minimalnya. Sedangkan multiple drugs resistance didefinisikan sebagai resistensi terhadap daua atau lebih obat maupun klasifikasi obat. Sedangkan cross resistance adalah resistensi suatu obat yang diikuti dengan obat lain yang belum pernah dipaparkan (Tripathi, 2003). Resistensi terjadi ketika bakteri berubah dalam satu atau lain hal yang menyebabkan turun atau hilangnya efektivitas obat, senyawa kimia atau bahan lainnya yang digunakan untuk mencegah atau mengobati infeksi. Bakteri yang mampu bertahan hidup dan berkembang biak, menimbulkan lebih banyak bahaya. Kepekaan bakteri terhadap kuman ditentukan oleh kadar hambat minimal yang dapat 
menghentikan perkembangan bakteri (Bari,2008). Timbulnya resistensi terhadap suatu antibiotika terjadi berdasarkan salah satu atau lebih mekanisme berikut :

\section{Bakteri mensintesis suatu enzim inaktivator atau penghancur antibiotika . Misalnya Stafilokoki, resisten terhadap penisilin $\mathrm{G}$ menghasilkan beta-laktamase, yang merusak obat tersebut. Beta-laktamase lain dihasilkan oleh bakteri batang Gram-negatif.}

2.Bakteri mengubah permeabilitasnya terhadap obat. Misalnya tetrasiklin, tertimbun dalam bakteri yang rentan tetapi tidak pada bakteri yang resisten.

3.Bakteri mengembangkan suatu perubahan struktur sasaran bagi obat. Misalnya resistensi kromosom terhadap aminoglikosida berhubungan dengan hilangnya (atau perubahan) protein spesifik pada subunit 30s ribosom bakteri yang bertindak sebagai reseptor pada organisme yang rentan.

4.Bakteri mengembangkan perubahan jalur metabolik yang langsung dihambat oleh obat. Misalnya beberapa bakteri yang resisten terhadap sulfonamid tidak membutuhkan PABA ekstraseluler, tetapi seperti sel mamalia dapat menggunakan asam folat yang telah dibentuk.

5.Bakteri mengembangkan perubahan enzim yang tetap dapat melakukan fungsi metabolismenya tetapi lebih sedikit dipengaruhi oleh obat dari pada enzim pada kuman yang rentan. Misalnya beberapa bakteri yang rentan terhadap sulfonamid, dihidropteroat sintetase, mempunyai afinitas yang jauh lebih tinggi terhadap sulfonamid dari pada PABA (Jawetz, 1997).

Penyebab utama resistensi antibiotika adalah penggunaannya yang meluas dan irasional. Lebih dari separuh pasien dalam perawatan rumah sakit menerima antibiotik sebagai pengobatan ataupun profilaksis. Sekitar 80\% konsumsi antibiotik dipakai untuk kepentingan manusia dan sedikitnya $40 \%$ berdasar indikasi yang kurang tepat, misalnya infeksi virus. Terdapat beberapa factor yang mendukung terjadinya resistensi,antara lain

1. Penggunaannya yang kurang tepat (irrasional) : terlau singkat, dalam dosis yang terlalu rendah, diagnose awal yang salah, dalam potensi yang tidak adekuat. 
2. Faktor yang berhubungan dengan pasien . Pasien dengan pengetahuan yang salah akan cenderung menganggap wajib diberikan antibiotik dalam penanganan penyakit meskipun disebabkan oleh virus, misalnya flu, batuk-pilek, demam yang banyak dijumpai di masyarakat. Pasien dengan kemampuan financial yang baik akan meminta diberikan terapi antibiotik yang paling baru dan mahal meskipun tidak diperlukan. Bahkan pasien membeli antibiotika sendiri tanpa peresepan dari dokter (self medication). Sedangkan pasien dengan kemampuan financial yang rendah seringkali tidak mampu untuk menuntaskan regimen terapi.

3. Peresepan : dalam jumlah besar, meningkatkan unnecessary health care expenditure dan seleksi resistensi terhadap obat-obatan baru. Peresepan meningkat ketika diagnose awal belum pasti. Klinisi sering kesulitan dalam menentukan antibiotik yang tepat karena kurangnya pelatihan dalam hal penyakit infeksi dan tatalaksana antibiotiknya.

4. Penggunaan monoterapi : dibandingkan dengan penggunaan terapi kombinasi, penggunaan monoterapi lebih mudah menimbulkan resistensi.

5. Perilaku hidup sehat : terutama bagi tenaga kesehatan, misalnya mencuci tangan setelah memeriksa pasien atau desinfeksi alat-alat yang akan dipakai untuk memeriksa pasien.

6. Penggunaan di rumah sakit : adanya infeksi endemic atau epidemic memicu penggunaan antibiotika yang lebih massif pada bangsalbangsal rawat inap terutama di intensive care unit. Kombinasi antara pemakaian antibiotic yang lebih intensif dan lebih lama dengan adanya pasien yang sangat peka terhadap infeksi, memudahkan terjadinya infeksi nosokomial.

7. Penggunaannya untuk hewan dan binatang ternak : antibiotic juga dipakai untuk mencegah dan mengobati penyakit infeksi pada hewan ternak. Dalam jumlah besar antibiotic digunakan sebagai suplemen rutin untuk profilaksis atau merangsang pertumbuhan hewan ternak. Bila dipakai dengan dosis subterapeutik, akan meningkatkan terjadinya resistensi.

8. Promosi komersial dan penjualan besar-besaran oleh perusahaan 
farmasi serta didukung pengaruh globalisasi, memudahkan terjadinya pertukaran barang sehingga jumlah antibiotika yang beredar semakin luas. Hal ini memudahkan akses masyarakat luas terhadap antibiotika

9. Penelitian : kurangnya penelitian yang dilakukan para ahli untuk menemukan antibiotika baru (Bisht et al, 2009)

10. Pengawasan : lemahnya pengawasan yang dilakukan pemerintah dalam distribusi dan pemakaian antibiotika. Misalnya, pasien dapat dengan mudah mendapatkan antibiotika meskipun tanpa peresepan dari dokter. Selain itu juga kurangnya komitmen dari instansi terkait baik untuk meningkatkan mutu obat maupun mengendalikan penyebaran infeksi (Kemenkes RI, 2011).

\section{Konsekuensi}

$$
\begin{aligned}
& \text { Resistensi antibiotik terhadap } \\
& \text { mikroba menimbulkan beberapa } \\
& \text { konsekuensi yang fatal. Penyakit } \\
& \text { infeksi yang disebabkan oleh bakteri } \\
& \text { yang gagal berespon terhadap } \\
& \text { pengobatan mengakibatkan } \\
& \text { perpanjangan penyakit (prolonged } \\
& \text { illness), meningkatnya resiko kematian } \\
& \text { (greater risk of death) dan semakin }
\end{aligned}
$$

lamanya masa rawat inap di rumah sakit (length of stay). Ketika respon terhadap pengobatan menjadi lambat bahkan gagal, pasien menjadi infeksius untuk beberapa waktu yang lama (carrier). Hal ini memberikan peluang yang lebih besar bagi galur resisten untuk menyebar kepada orang lain. Kemudahan transportasi dan globalisasi sangat memudahkan penyebaran bakteri resisten antar daerah, negara, bahkan lintas benua. Semua hal tersebut pada akhirnya meningkatkan jumlah orang yang terinfeksi dalam komunitas (Deshpande et al, 2011)

Ketika infeksi menjadi resisten terhadap pengobatan antibiotika lini pertama, maka harus digunakan antibiotika lini kedua atau ketiga, yang mana harganya lebih mahal dan kadang kala pemakaiannya lebih toksik. Di negara-negara miskin, dimana antibiotika lini pertama maupun kedua tidak tersedia, menjadikan potensi resistensi terhadap antibiotika lini pertama menjadi lebih besar. Antibiotika di Negara miskin, didapatkan dalam jumlah sangat terbatas, bahkan antibiotika yang seharusnya ada untuk mengatasi penyakit infeksi yang disebabkan 
bakteri pathogen resisten, tidak ampuh mengatasi masalah resistensi terdaftar dalam daftar obat esensial (Bhatia \& Narain, 2010)

(Bisht et al, 2009)

Konsekuensi lainnya adalah dari segi ekonomi baik untuk klinisi, pasien, health care administrator, perusahaan farmasi, dan masyarakat. Biaya kesehatan akan semakin meningkat seiring dengan dibutuhkannya antibiotika baru yang lebih kuat dan tentunya lebih mahal. Sayangnya, tidak semua lapisan masyarakat mampu menjangkau antibiotika generasi baru tersebut. Semakin mahal antibiotik, semakin masyarakat tidak bisa menjangkau, semakin banyak carrier di masyarakat, semakin banyak galur baru bakteri yang bermutasi dan menjadi resisten terhadap antibiotika.

Sampai sekarang, faktanya sangat sulit membayangkan adanya prosedur yang efektif untuk menangani resistensi ini. Klinisi akan sangat kesulitan menentukan keputusan regimen terapi pada pasien-pasien dengan resiko infeksi tinggi, misalnya pada pasien yang akan menjalani prosedur bedah, transpalntasi, pasien dengan kemoterapi karena kanker, pasien-pasien kritis yang berusia sangat muda atau sangat tua, pasien HIV dalam masa pengobatan, tanpa keberadaaan antibiotika yang

\section{STRATEGI PENANGANAN}

Berdasarkan faktor pendukung yang telah diuraikan dalam bab sebelumnya, maka strategi penanganan maupun pencegahan yang dapat dilakukan yang pertama dan utama adalah terapi rasional. Penggunaan antibiotika secara rasional diartikan sebagai pemberian antibiotika yang tepat indikasi, tepat penderita, tepat obat, tepat dosis, dan waspada terhadap efek samping antibiotika.

Kapan saat yang tepat memulai terapi antibiotika? Secara klinik memang sangat sulit memastikan bakteri penyebab infeksi yang tepat tanpa menunggu hasil pemeriksaan mikrobiologi. Secara umum, klinisi tidak boleh memberikan terapi secara sembarangan tanpa mempertimbangkan indikasi atau malah menunda pemberian antibiotika pada kasus infeksi yang sudah tegak diagnosanya secara klinis meskipun tanpa hasil pemeriksaan mikrobiologi. Kasus infeksi yang gawat dapat berupa sepsis, demam dengan neutropeni, meningitis bakterial (Leekha et al, 2011). 


\begin{abstract}
Berdasarkan ditemukannya kuman atau tidak, maka terapi antibiotika dapat dibagi dua, yakni terapi empiris dan terapi definitive. Terapi empiris adalah terapi yang diberikan berdasar diagnose klinis dengan pendekatan ilmiah dari klinisi. Sedangkan terapi definitive dilakukan berdasarkan hasil pemeriksaan mikrobiologis yang sudah pasti jenis kuman dan spectrum kepekaan antibiotikanya (Jawetz, 1997).
\end{abstract}

Untuk menentukan penggunaan antibiotika dalam menangani penyakit infeksi, secara garis besar dapat dipakai prinsip-prinsip umum dibawah ini :

1. Penegakan diagnosis infeksi. Hal ini bisa dikerjakan secara klinis berdasar criteria diagnose ataupun pemeriksaan-pemeriksaan tambahan lain yang diperlukan. Gejala panas sama sekali bukan kriteria untuk diagnosis adanya infeksi.

2. Kemungkinan kuman penyebabnya, dipertimbangkan dengan perkiraan ilmiah berdasarkan pengalaman setempat yang layak dipercaya atau epidemiologi setempat atau dari informasi-informasi ilmiah lain.

3. Apakah antibiotika benar-benar diperlukan? Sebagian infeksi mungkin tidak memerlukan terapi antibiotika misalnya infeksi virus saluran pernafasan atas, keracunan makanan karena kontaminasi kuman-kuman enterik. Jika tidak perlu antibiotika, terapi alternatif apa yang dapat diberikan?

4. Jika diperlukan antibiotika, pemilihan antibiotika yang sesuai berdasarkan spektrum antikuman, sifat farmakokinetika, ada tidaknya kontra indikasi pada pasien, ada tidaknya interaksi yang merugikan, bukti akan adanya manfaat klinik dari masing-masing antibiotika untuk infeksi yang bersangkutan berdasarkan informasi ilmiah yang layak dipercaya. Dari sisi bakteri, pertimbangkan site of infection and most likely colonizing, berdasar pengalaman atau evidence based sebelumnya bakteri apa yang paling sering, pola kepekaan antibiotika yg beredar local (Leekha et al, 2011).

5. Penentuan dosis, cara pemberian, lama pemberian berdasarkan sifatsifat kinetika masing-masing antibiotika dan fungsi fisiologis sistem tubuh (misalnya fungsi ginjal, fungsi hepar dan lain-lain). Perlu dipertimbangkan dengan cermat pemberian antibiotika 
misalnya pada ibu hamil dan menyusui, anak-anak, dan orang tua.

6. Evaluasi efek obat. Apakah obat bermanfaat, kapan dinilai, kapan harus diganti atau dihentikan? Adakah efek samping yang terjadi? (Graham-Smith \& Aronson, 1985)

Selain hal-hal di atas, edukasi pasien juga merupakan hal yang penting untuk dilakukan. Banyak penelitian menunjukkan bahwa edukasi atau training yang diberikan kepada kelompok besar maupun kecil, menunjukkan peningkatan peresepan antibiotic yang baik. Pesan akan diterima dengan baik apabila disampaikan oleh pemimpin local atau orang yang dianggap berpengaruh (Bisht et al, 2009). Pesan dapat disampaikan melalui berbagai media misalnya melalui iklan di televisi, radio, koran. Tekhnologi komunikasi yang baru juga memudahkan penyebaran informasi ini, misalnya internet, jejaring sosial, bahkan lewat mobile messenger.

Perlu disebarluaskan bahwa tidak semua jenis penyakit dapat disembuhkan dengan pemberian antibiotik. Kalaupun perlu, pemakaian antibiotic harus sesuai dengan instruksi dokter baik dosis maupun rentang terapinya. Pada penyakit-penyakit kronis seringkali pasien menghentikan sendiri atau mengurangi terapinya ketika sudah merasakan perbaikan yang signifikan atas penyakitnya. Untuk mengatasi hal ini, diciptakanlah obat dalam fixed dose combinations untuk mengurangi jumlah tablet atau kapsul yang harus diminum, kalender special, kemasan blister, DOTS (directly observed therapy system).

Tenaga kesehatan harus lebih sadar terhadap personal and environmental hygiene agar infeksi bakteri tidak menyebar dari satu orang ke orang lain. Dokter misalnya, dapat mencuci tangan terlebih dahulu setelah memeriksa pasien yang satu sebelum beralih ke pasien yang lain. Bidan wajib menerapkan prinsip sepsis-asepsis dalam memolong persalinan. Alat-alat operasi, KB, ataupun piranti rumah sakit yang harus suci kuman wajib dusterilisasi terlebih dahulu.

Di Indonesia, juga telah dilakukan beberapa usaha untuk mengatasi dampak resistensi antibiotika akibat pengobatan sendiri (self medication) dengan regulasi perundang-undangan.. Salah satu dari usaha tersebut adalah di berlakukannya undang-undang yang 
mengatur tentang penjualan antibiotika yang diatur di dalam undang-undang obat keras St. No. 419 tgl. 22 Desember 1949, pada pasal 3 ayat 1. Antibiotika termasuk salah satu jenis obat-obat keras, hal ini terdapat dalam pasal 1 ayat 1a yang berbunyi: "Obat-obat keras yaitu obat-obatan yang tidak digunakan untuk keperluan teknik, yang mempunyai khasiat mengobati, menguatkan, membaguskan, mendesinfeksikan, dan lain-lain tubuh manusia, baik dalam bungkusan maupun tidak, yang dtetapkan oleh Secretaris Vaan Staat, Hoofd van het Departement van Gesondheid, menurut ketentuan pasal 2 ayat (1) "Sec. V. St mempunyai wewenang untuk menetapkan bahan-bahan sebagai obatobat keras dan ayat (2) “ Penetapan ini dijalankan dengan menempatkan bahanbahan itu pada suatu daftar G (obat-obat berbahaya) atau daftar W (peringatan).

Dalam Pasal 107 UU No. 36/2009 tentang Kesehatan ada ketentuan lebih lanjut mengenai pengamanan sediaan farmasi seperti obat antibiotik dan alat kesehatan dilaksanakan sesuai dengan ketentuan peraturan perundangundangan. Pasal 108 (1) mengatur praktik kefarmasian yang meliputi pembuatan termasuk pengendalian mutu sediaan farmasi, pengamanan, pengadaan, penyimpanan, dan pendistribusian obat, pelayanan obat atas resep dokter, pelayanan informasi obat serta pengembangan obat,bahan obat dan obat tradisional harus dilakukan oleh tenaga kesehatan yang mempunyai keahlian dan kewenangan sesuai dengan ketentuan peraturan perundang-undangan.

Peraturan mengenai distribusi obat tertulis dalam (Direktorat Jenderal Pelayanan Kefarmasian dan Alat Kesehatan) :

1) Pasal 3 (1) Penyerahan persediaan untuk penyerahan dan penawaran untuk penjualan dari bahan-bahan $\mathrm{G}$, demikian pula memiliki bahan bahan ini dalam jumlah sedemikian rupa sehingga secara normal tidak dapat diterima bahwa bahan-bahan ini hanya diperuntukkan pemakain pribadi, adalah dilarang. Larangan ini tidak berlaku untuk pedagangpedagang besar yang diakui, Apoteker-apoteker , yang memimpin Apotek dan Dokter Hewan.

2) (2) Penyerahan dari bahan -bahan G , yang menyimpang dari resep Dokter, Dokter Gigi, Dokter Hewan dilarang, larangan ini tidak berlaku 
bagi penyerahan-penyerahan kepada Pedagang -pedagang Besar yang diakui, Apoteker-apoteker, Dokterdokter Gigi dan Dokter-dokter Hewan demikian juga tidak terhadap penyerahan-penyerahan menurut ketentuan pada pasal 7 ayat 5 (Keputusan Menkes RI, 2004).

Selain peraturan perundangundangan, klinisi memerlukan guideline terapi antibiotika yang dapat digunakan sebagai dasar terapi empiris di klinik. Pelaksanaan penggunaan guideline ini seyogyanya dievaluasi secara ketat oleh pihak yang terkait misalnya rumah sakit atau dinas kesehetan. Dalam mengaplikasikan guideline ini, tentunya klinisi akan sangat terbantu dengan keberadaan laboratorium mikrobiologi klinik yang mampu menyediakan hasil pemeriksaan secepat mungkin dan mendiskusikan hasilnya dengan klinisi. Mutu obat sebaiknya diawasi dan dievaluasi secara berkala. Para professional hendaknya mulai menggalakkan penelitian untuk menemukan antibiotika baru yang lebih poten dalam melawan bakteri resistan.

Dengan cepatnya dan makin seringnya diperkenalkan berbagai jenis antibiotika dan kemoterapetika baru, praktisi sering mendapatkan kesulitan dalam menilai manfaat, peran serta resiko dari suatu jenis obat baru dibandingkan dengan jenis-jenis yang sudah ada. Hal ini sering diperburuk oleh kenyataan bahwa informasi yang diberikan mengenai obat yang baru, lebih sering banyak menonjolkan segi manfaat dan kelebihannya, sedangkan efek samping dan kekurangankekurangan lainnya cenderung diperkecilkan. Di lain pihak, informasi ilmiah dalam bukubuku pustaka untuk obat yang baru diperkenalkan umumnya masih kurang lengkap. Menghadapi kesulitan ini reaksi yang timbul dapat muncul secara ekstrim dalam dua kemungkinan. Pertama, mengikuti saja semua informasi dan anjuran yang diterima, walaupun informasinya belum tentu sepenuhnya benar. Kedua, secara apriori langsung menolak semua informasi dan anjuran tanpa terlebih dulu apakah ada kelebihan manfaat dari obat baru yang diperkenalkan tersebut.

Menghadapi suatu jenis antibiotika baru yang diperkenalkan, maka langkah-langkah penelaahan yang dianjurkan adalah sebagai berikut,

ermasuk jenis apakah antibiotika baru tersebut?

- Bagaimanaspektrum antikumannya? 
- Apa indikasi pemakaian kliniknya?

- Apa antibiotika pilihan utama dan pilihan alternatif untuk kondisi klinik atau infeksi yang dimaksud?

- Apakah antibiotika baru secara mikrobiologik lebih aktif, atau lebih paten dibanding antibiotika yang sudah ada untuk infeksi bersangkutan?

- Apakah ada kelebihan lain secara farmakologik, misalnya dalam sifatsifat kinetik, absorpsi, distribusi dan penetrasi jaringan, eliminasi, cara pemberian, dosis dan sebagainya?

- Apakah antibiotika baru memberikan manfaat klinik lebih baik dibanding yang sudah ada? Dan apakah bukti manfaat klinik ini ditunjang oleh penelitian uji klinik yang dapat diterima, misalnya dengan rancangan randomized controlled trial?

- Apakah antibiotika baru lebih aman, kurang toksik atau kurang efek sampingnya dibanding yang sudah ada?

- Apakah beaya pemakaian kliniknya lebih murah dibandingkan dengan obat yang sudah ada dengan manfaat klinik dan keamanan yang sebanding?
- Apakah antibiotika baru tersebut dapat dipakai secara rutin, ataukah hanya dipakai sebagai cadangan atau simpanan (reserved antibiotics) untuk menghadapi kasus-kasus khusus yang tidak dapat diatasi dengan antibiotika yang sudah ada? (Petunjuk kuliah farmakoterapi, 2010).

\section{KESIMPULAN}

Masalah antibiotika dan resistensinya menjadi perhatian seluruh dunia. WHO bahkan menetapkan tema Antimicrobacterial Resistance and its Global Spread untuk memperingati Hari Kesehatan Sedunia. Penanganan masalah ini memerlukan partisipasi dari banyak pihak. Dokter sebagai klinisi, masyarakat luas sebagai pengguna, pemerintah sebagai pemegang regulasi, farmasi sebagai distributor, bahkan calon tenaga kesehatan bisa berperan serta dalam menangani masalah resistensi ini.

\section{DAFTAR PUSTAKA}

Akalin, E. H. 2002. The evolution of guidelines in an era of cost containment. Surgical prophylaxis. J Hosp infect.

APUA (Alliance for prudent use of antibiotics). 2011. What is antibiotic resistance and why is 
it problem?. www.apua.org on 16-09-2011.

Bari, S. B., Mahajan, B. M., Surana, S. J. 2008. Resistance to antibiotic : A challenge in chemotherapy. Indian journal of pharmaceutical education and research.

Bhatia, R., Narain, J. P. 2010. The growing challenge of antimicrobial resistance in the south east asia region- Are we losing the battle?. Indian Journal of medical research.

Bisht, R., Katiyar, A., Singh, R., Mittal, P. 2009. Antibiotic resistance- A global issue of concern. Asian journal of pharmaceutical and clinical research. Volume 2. Issue 2.

Deshpande, J. D., Joshi, M. 2011. Antimicrobial resistance : the global public health challenge. International journal of student research. Volume I. Issue 2.

Grahame-Smith, D. G., Aronson, S. K. 1985. Oxford textbook of clinical pharmacology and drug therapy. Oxford University press, Oxford.

Jawetz, E. 1997. Principle of antimicrobial drug action. Basic and clinical pharmacology. Third edition. Appleton and Lange, Norwalk.

Kementrian Kesehatan Republik Indonesia. 2011. Buku panduan hari kesehatan sedunia.
Keputusan Menteri Kesehatan tentang standard pelayanan farmasi di Rumah Sakit. 2004. No 1197/MENKES/SK/X/2004.

Laurence, D. R., Bennet, P. N. 1987. Clinical Pharmacology. Sixth edition. Churchill livingstone, Edinburgh.

Leekha, S., Terrel, C. L., Edson, R. S. 2011. General principles of antimicrobial therapy. Symposium on antimicrobial therapy. Februari.

Munaf, S., Chaidir, J. 1994. Obat antimikroba. Farmakologi UNSRI. EGC, Jakarta.

Peterson, L. R. 2005. Squeezing the antibiotic balloon : The impact of antimicrobial classes on ermerging resistance. European society of clinical microbiology and infectious deseases. The Feinberg school of medicine, North Western University, USA.

Petunjuk kuliah/diskusi : Farmakoterapi antiinfeksi/antibiotika. 2010. Bagian farmakologi klinik Fakultas Kedokteran Universitas Gajah Mada.

Tripathi, K. D. 2003. Antimicrobial drugs : general consideration. Essential of medical pharmacology. Fifth edition. Jaypee brothers medical publishers.

Zhang, Y. 2007. Mechanisms of antibiotic resistance in the 
Antibioka, Resistensi, dan Rasionalitas Terapi

microbial world. Baltimore, USA. 